\begin{tabular}{|c|c|c|}
\hline \multirow[t]{2}{*}{$\frac{\mathrm{DE}}{\bar{C}}$} & $\begin{array}{l}\text { DE GRUYTER } \\
\text { OPEN }\end{array}$ & ECONOMIC THEMES (2017) 55(2): 143-159 \\
\hline & & DOI 10.1515/ethemes-2017-0009 \\
\hline
\end{tabular}

\title{
KEY POLICY RATE AS THE MAIN OR ADDITIONAL INSTRUMENT OF INFLATION TARGETING STRATEGY IN SERBIA
}

\author{
Srđan Furtula* \\ University of Kragujevac, Faculty of Economics, Republic of Serbia \\ $\triangle$ furtulas@kg.ac.rs \\ Milan Kostić \\ University of Kragujevac, Faculty of Economics, Republic of Serbia \\ $\triangle$ mkostic@kg.ac.rs
}

UDC
$336.711(49$
$7.11)$
$338.23: 336$.
$74(497.11))$
Review
paper

Received:

15.07.2016.

Accepted:

05.05.2017.

\begin{abstract}
In achieving price stability as the primary objective of monetary policy, the National Bank of Serbia uses the key policy rate as the main instrument of monetary policy, while other instruments have a supporting role - contribute to a smooth transmission of the key policy rate on the market, as well as the development of financial markets. However, because the conditions in which economic and financial system of the Republic of Serbia works, transmission mechanism of monetary policy is conducted mainly through the exchange rate channel, while the channel of interest rates almost did not work. The great impact the exchange rate channel is determined by the great influence of the single currency euro and the ECB on our country. Therefore, the aim of this paper is to analyse the efficiency of the key policy rate as a monetary policy instrument, because in recent years the primary instrument receives a secondary character in the monetary regulation.
\end{abstract}

Keywords: National Bank of Serbia, inflation, monetary policy, key policy rate, foreign exchange market.

JEL classification: E31, E42, E52

\section{Introduction}

* The article is the result of research on Project no. 42013 funded by the Ministry of Education, Science and Technological Development of Republic of Serbia 
Monetary policy instruments influence the economy in different manners and have different effects on prices and production. Therefore, it is very important to accurately define and determine the transmission mechanism of monetary policy. The monetary transmission mechanism is a combination of all economic channels through which, during a certain period, monetary policy affects the economy. In the European Monetary Union, the interest rate channel has a dominant role in monetary policy transmission.

Changes in interest rates have a direct impact on market interest rates and on the prices of financial assets, such as bonds, stocks, and exchange rate. Changes in nominal interest rates affect real interest rates and asset prices. Influencing consumption and imbalancing between supply and demand, changes in interest rates affect wages and prices with a certain delay. Time lag depends on inflation expectations as well. In a relatively closed economy such as the Eurozone, domestic channels have the key role in the monetary transmission. Interest rate channel has four sub-channels, through which monetary transmission operates (eg. in the case of an increase in interest rates) (ECB, 2002, p. 44):

1. Substitution channel - Temporary increase in interest rates affects the population to postpone consumption, reduces demand, and increases savings,

2. Wealth channel - Changes in prices of stocks, bonds, and property affect the wealth of the population, and therefore the spending as well,

3. Income channel - Changes in interest rates directly affect the income of the population,

4. Channel of the cost of capital - Changes in interest rates affect the costs of providing new capital and affect the change in demand for investment goods.

If we observe the Eurozone, it can be concluded that the monetary transmission mechanism operates in a similar manner in all states of the Eurozone, through the interest rate channel. Banks play a key role in the interest rate channel, by transmitting the effects of the key policy rate on lending and deposit interest rates, given the large share of banks in financing companies and the population. Differences in certain states in the transmission mechanism of monetary policy in EMU are the result of new financial products and new participants, the changing nature of competition between banks, and different level of integration of financial market in some states of the Eurozone. In addition to the dominant influence of the interest rate channel, other channels of monetary transmission in the Eurozone are credit channel and channel of inflation expectations.

Unlike the transmission channel of monetary policy in the ECB, in the NBS the exchange rate channel has a dominant role. Large impact of the euro and the ECB on our economy is the reason for the dominant influence of the exchange rate channel, since deposits and loans are indexed to the European currency. Unlike the 
ECB, in the first years of transition, the transmission mechanism of the monetary policy in Serbia was carried out mainly through the exchange rate channel, while the interest rate channel almost did not work. With the new monetary framework, formulated in September 2006, the emphasis was placed on the key policy rate, which is defined as the main instrument, and the aim was to strengthen credit and interest rate channel.

The same as in the European Central Bank, which with the Article 105 of the Maastricht Treaty defined that the primary objective of the ECB is price stability, the main objective of the National Bank of Serbia, defined by the Article 3 of the Law on the National Bank of Serbia (Official Gazette of R. Serbia, no. 72/03, $55 / 04,85 / 05,44 / 10,76 / 12,106 / 12,14 / 15$ and 40/15) is also to achieve and maintain price stability. In addition to its primary objective, the National Bank of Serbia will also pursue the objective of financial stability. Without prejudice to its primary objective, the National Bank of Serbia will support the economic policies of the Government which are conducive to sustainable economic growth. With the Memorandum on the New Monetary Policy Framework, adopted in August 2006, the practice of inflation targeting has been introduced gradually. Formal implementation of the inflation targeting regime was defined by the Memorandum on Inflation Targeting as Monetary Strategy, as of 1 January 2009. The main principles of the inflation targeting in Serbia are as follows (NBS):

1. The inflation target, defined in terms of the annual percentage change in the consumer price index, is the only numerical guideline for the monetary policy implemented by the National Bank of Serbia. The National Bank of Serbia will support the implementation of the economic policy of the Government if this does not threaten the achievement of the inflation target or the stability of the financial system, the same as in the ECB;

2. The National Bank of Serbia will achieve the inflation target by changing the interest rate applied in the conduct of its main monetary policy operations. This interest rate will be its main monetary policy instrument. Other monetary policy instruments will have supporting roles, as they should contribute to a smooth transmission of the key policy rate to the market and balanced development of financial markets without threatening the stability of the financial system.

The inflation target is determined by the National Bank of Serbia in cooperation with the Government, based on the analysis of current and expected macroeconomic developments and medium-term plan to change prices on which the Government has a direct or indirect impact. Target for inflation is determined as a unique value with tolerance, measured by the annual percentage change in the consumer price index, for several years ahead.

The National Bank of Serbia is using the inflation targeting strategy of monetary policy as the result of major inflationary expectations in our country, the 
negative trends of the past in terms of inflationary trends and the interests of harmonisation with the European Central Bank. In order to effectively control the exchange rate and monetary policy transmission, the National Bank of Serbia has chosen a managed floating exchange rate regime, with the possibility of correction. The exchange rate is flexible and is formed at the interbank foreign exchange market on the basis of supply and demand of foreign exchange, and the NBS in case of excessive daily oscillations intervene by selling or buying foreign currency. If the NBS wants to absorb liquidity and prevent the depreciation of domestic currency, the NBS will intervene by selling foreign currency on the interbank foreign exchange market, and vice versa. The NBS carried out foreign exchange intervention with Reuters Dealing System and organised auctions of foreign exchange spot.

In economic theory, there are conflicting opinions on the use of foreign exchange intervention in the inflation targeting regime. Lars Svensson says that there is no reason why a transparent inflation-targeter should undertake foreign exchange interventions (Svensson, 2001). On the other side, central bankers claim that interventions play a role in monetary policy instruments. However, there should be difference between sterilised and non-sterilised foreign exchange interventions. As long as foreign exchange interventions are sterilised and do not use the monetary base and thus leave short-term interest rates unchanged, they provide an independent instrument for monetary policy. (Hufner, 2004)

Since intervention in the foreign exchange market is characterised as an additional instrument of monetary policy and the key policy rate as the main instrument, the purpose of this paper is to analyse weather the National Bank of Serbia, as inflation targeting central bank uses the key policy rate as an additional instrument, because of many foreign exchange interventions and small impact of the key policy rate on other rates in the banking sector.

\section{Low Influence of Key Policy Rate and Inflation Rate on Active and Passive Interest Rate}

With the new monetary policy framework from 2006, the key policy rate becomes the main monetary policy instrument, and other instruments get supporting roles. They should contribute to a smooth transmission of the key policy rate to the market and the development of financial markets, where the stability of the financial system would not be threatened.

The transmission mechanism of monetary policy in Serbia in the first years of transition was carried out mainly through the exchange rate channel, while the interest rate channel almost did not work. Active use of required reserve from the beginning of 2005 until the second half of 2006, as an instrument of monetary policy, aimed to strengthen credit and interest rate channel. During this period, 
almost every month, the rate of foreign currency of required reserve was changed upwards or its basis for calculation was expanded.

Interest rate channel is the most important channel of monetary transmission mechanism in developed market economies. It is manifested in the way that the central bank, by changing the key policy rate, causes changes in short-term nominal interest rates, which, in line with inflationary expectations, affect the longterm interest rates. Long-term real interest rates affect the scope and structure of consumption, propensity for saving and investments. The average interest rate can be considered representative or reference if it has three main features.

First, it is calculated in the deep liquid market. Such market is very competitive, therefore no participant can influence the interest rate with a large amount of loan/deposit or deliberate manipulation. Calculation of equilibrium average, based on a large number of transactions, ensures representativeness and stability of the interest rate calculated in this manner.

Second, the key policy rate is influenced by basic money market interest rates. Central banks determine the basic money market interest rates in accordance with the objectives of monetary policy.

Third, the representativeness of the interest rate makes it reference. This means that in many loan agreements it appears as the basis for calculating the final active interest rate paid by the borrower. In this way, the interest rate becomes variable depending on the movement of the key policy rate.

In the world of finance, nowadays there are several key interest rates for several key currencies. The most famous among them are certainly LIBOR (London Interbank Offered Rate). LIBOR or LIBORs are calculated according to the methodology of the British Bankers' Association, for different maturities and different currencies that are traded in the London money market. LIBOR is an average daily benchmark rate based on the interest rates at which banks grant unsecured loans.

LIBOR is announced by the British Bankers' Association every day, after 11 am (usually somewhere around 1145) London time. US dollar LIBOR is the interest rate at which banks on the London money market are prepared to lend one another money, by depositing US dollars in the bank. Euro LIBOR rate is the same kind of deposit in euros. Panel group, which is used to determine the US dollar LIBOR, consists of 16 banks for Euro LIBOR, also 16 banks for Australian dollar, 8 banks for Danish krone, and encompasses 12 banks for Canadian dollar and Swiss franc.

Tibor (Tokyo Interbank Offered Rate) is announced by Japan's Banking Federation every working day at 11am, as an average of interest rates offered 
during the period of one week for interbank unsecured lending with maturities of one week up to 12 months. The panel consists of 16 banks.

EONIA (European Over Night Index Avarage) is the average rate of loans in euros, with a duration of 24 hours without collateral, which are approved in the European interbank daily money market. One of the daily duties of the ECB is to set the rate of EONIA and publish it to the European Banking Federation. The reason why the calculation of EONIA rate is within the competence of the European Central Bank is the fact that EONIA depended on the amount of night loans of commercial banks, which were confidential. It is calculated based on the daily quotation interest rates of 51 Eurozone banks, members of the Panel group. The Panel group consists of the banks with the largest volume of transactions in the money market in the Eurozone. The Panel group consisting of:

- Banks of the EMU Member States,

- Banks of the EU Member States, and

- Large international banks of the states that are not EU members, but with a large share of operations in the Eurozone.

After closing the RTGS system at 06 pm, all banks in the Panel must, no later than 06.30 pm, inform the European Central Bank on all unsecured loans and the average interest rate at which the loans were granted. The European Central Bank determines EONIA rate between $06.45 \mathrm{pm}$ and $07 \mathrm{pm}$, Central European Time. Under normal circumstances, EONIA is close to the marginal rate of the main refinancing operations, i.e. key policy rates in the Eurozone.

EURIBOR (Euro Interbank Offered Rate) is the interest rate offered for interbank lending with some longer term. Euribor rate is supported by the European Banking Federation (FBE), which represents the interests of 5.000 banks, large and small, with asset of 20.000 billion euros and more than 2.3 million employees (EFB, 2009) in the EU member states, Norway, and Switzerland. It is determined by the Panel group of banks (the same group of 51 banks which participates in determining EONIA rate) as the average of interest rates, offered during a period of one week, for interbank unsecured lending with maturity of one week up to 12 months. It is determined each day as of $1045 \mathrm{am}$ and no later than 1100 am (EMMI, 2009). This is the key interest rate, i.e. the price of the euro in the European interbank market and banks use this interest rate as an active interest rate to which they add their own profit.

Organized rating of interest rates in the Serbian interbank market in the form of BEONIA and BELIBOR rates also contributes to intensifying the use of the interest rate channel in the transmission of monetary policy. The manner of determining BEONIA and BELIBOR is the same the European Monetary Union uses in determining the interest rate of EONIA and EURIBOR. 
BEONIA (Belgrade Overnight Index Average) is the effective overnight rate calculated as the weighted average of all overnight lending transactions in the Serbian interbank market, in which all banks participated. The National Bank of Serbia shall calculate and publish BEONIA rate and the total volume of loans on each business day at $0715 \mathrm{pm}$, Central European Time. Banks shall submit all necessary data on overnight loans (all RSD funds of interbank loans with repayment period up to the end of the next day), no later than 30 minutes after closing the RTGS system of the National Bank of Serbia. The minimum loan amount for which banks are required to submit the Report is 1.000 .000 dinars. The National Bank of Serbia publishes BEONIA rate on each business day, at the latest within 45 minutes from the lapse of the time period for the exchange of payment messages, as specified in operating rules on real time gross settlement (RTGS).

BELIBOR (Belgrade Interbank Offered Rate) is the benchmark rate offered on dinar deposits by Panel banks in the Serbian interbank market. BELIBOR rates are computed and published on the Reuters system each business day at 1100 am or $1115 \mathrm{am}$, as an arithmetic mean of daily quotes, after the elimination of the highest and the lowest rate, and are displayed with two decimal places precision. BELIBOR rates are published on http://thomsonreuters.rs/tr/rs/index.action each business day at 1130 am (Thomson Reuters Serbia, 2017).

The interest rates in the Serbian interbank market, BEONIA and BELIBOR, show the same tendency in the movement as the key policy rate and keep within the defined limits of the interest rate corridor ${ }^{1}$. Deviations from the key policy rate are the result of numerous restrictions and demands of foreign parent banks.

Due to the lack of projections on the assumption on constant key policy rate, and projections based on the interest rate path, the National Bank of Serbia uses inflation projections based on the key policy rate path, which it intends to follow.

Inflation projection of the National Bank of Serbia is made and published on a quarterly basis since 2006, based on endogenously determined key policy rate. Projection model contains the rule of Taylor-type monetary policy (NBS, 2016):

$$
i_{t}=a\left(i_{t-1}\right)+(1-a)\left[\left(r^{*}+\pi_{t}\right)+b\left(\pi_{t}-\pi^{*}\right)\right]
$$

$i_{t-1}$ represents previous key policy rate;

$r^{*}$ is equilibrium (neutral) real key policy rate (so that $\left(r^{*}+\pi_{t}\right)$ is equilibrium (neutral) nominal key policy rate);

$\left(\pi_{t}-\pi^{*}\right)$ represents a deviation of inflation from the target.

\footnotetext{
${ }^{1}$ Interest rate corridor is defined in relation to the key policy rate of the central bank. In the NBS, interest rate corridor is equal to the key policy rate of the NBS $+/-2.5 \%$, i.e. it represents a range of difference between the interest rates on credit facility and interest rate on deposit facility.
} 
The rule defines that the key policy rate should be below neutral when projected inflation is below the target and vice versa. In accordance with standard practice of central banks, the rule has an element which refers to the mitigation of changes in the key policy rate (the relative importance of stabilization of the main monetary policy instrument is expressed in the value of parameter $a$, from 0 to 1 ). The basic deviation from the Taylor rule is the exclusion of the impact of gap between real and projected GDP.

Opting for the key policy rate path, which a central bank intends to follow, is the result of efforts for inflation projections to influence equalisation of projected and targeted inflation at a given horizon of the target, in order to effectively impact inflation expectations.

The NBS's Executive Board, in accordance with the guidelines for determining the interest rates of open market operations, sets the level of the key policy rate and main interest rates at which NBS collects from banks and pays banks interest on the basis of transactions in the money market.

The key policy rate is the benchmark for all interest rates in the money market, i.e. the interest rate corridor. It is the highest and/or lowest interest rate applied by the National Bank of Serbia in the conduct of repo transactions of sale and/or purchase of securities, with maturity of two weeks $2 \mathrm{~W}$ (12 to 16 days). It contributes to keeping inflation within projected framework. Changes in the key policy rate are based on the assessment of the current economic situation, inflation trends, and its medium-term projection. If price stability is assessed as threatened, i.e. that actual inflation will be higher than projected, the key policy rate is projected upwards and vice versa. Higher key policy rate increases the_income of banks on secure loans, i.e. purchase of securities of the NBS, which affects the increase in lending rates, reduction in loans, and reduction in demand and inflation. The volume and time of these corrections take into account the delayed operation of monetary transmission and currently dominant role of the exchange rate channel. Since the beginning of 2007, the National Bank of Serbia has signaled the movement of the key policy rate in the near future, which is consistent with projected inflation.

In our country, after the introduction of the new monetary policy framework, less correlation between the key policy rate, interest rates in the interbank market and lending and deposit interest rates of banks can be noticed, despite the interest rate channel. Banks made the decision on the level of active and passive interest rates in relation to the movement of interest rates in the international market.

From Figure 1 it can be concluded that the key policy rate is almost identical with saving account interest rate, even in certain periods is moving below the saving account interest rate, while the lending rate is significantly above the key policy rate and is higher by $250 \%$. 
Due to the implementation of rational conclusions it is necessary to observe the rate of inflation due to the risk premium involved in lending and saving account interest rates in the RSD.

Figure 1. Interest rate on deposits, consumer loans and key policy rate

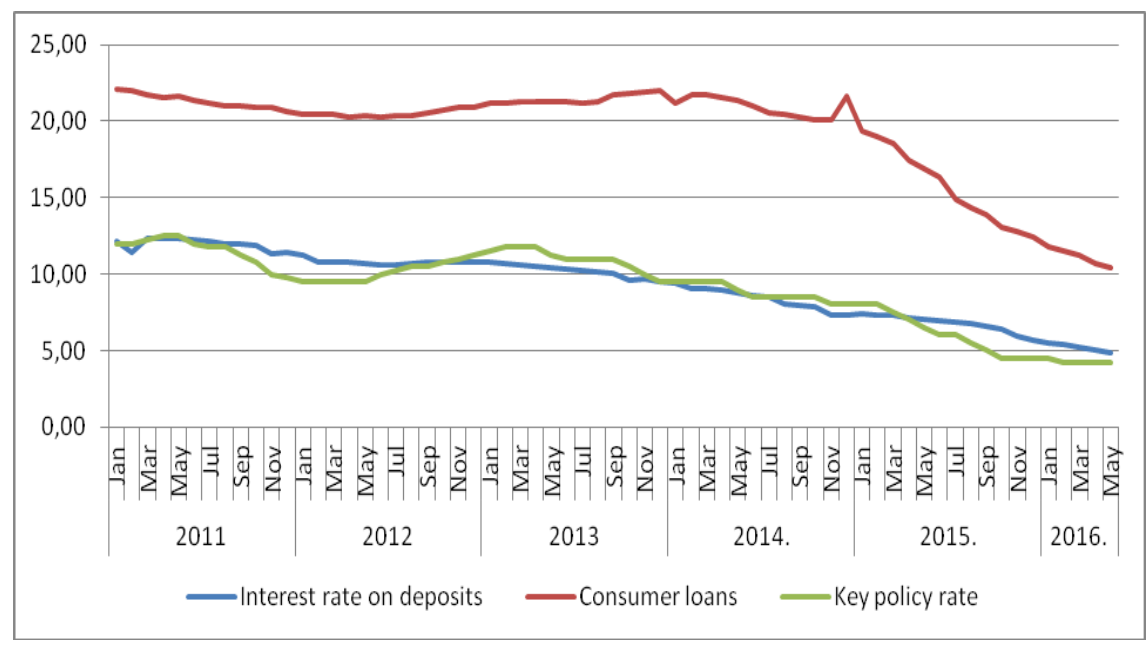

Source: NBS

Figure 2. Interest rate on deposits, consumer loans and inflation rate

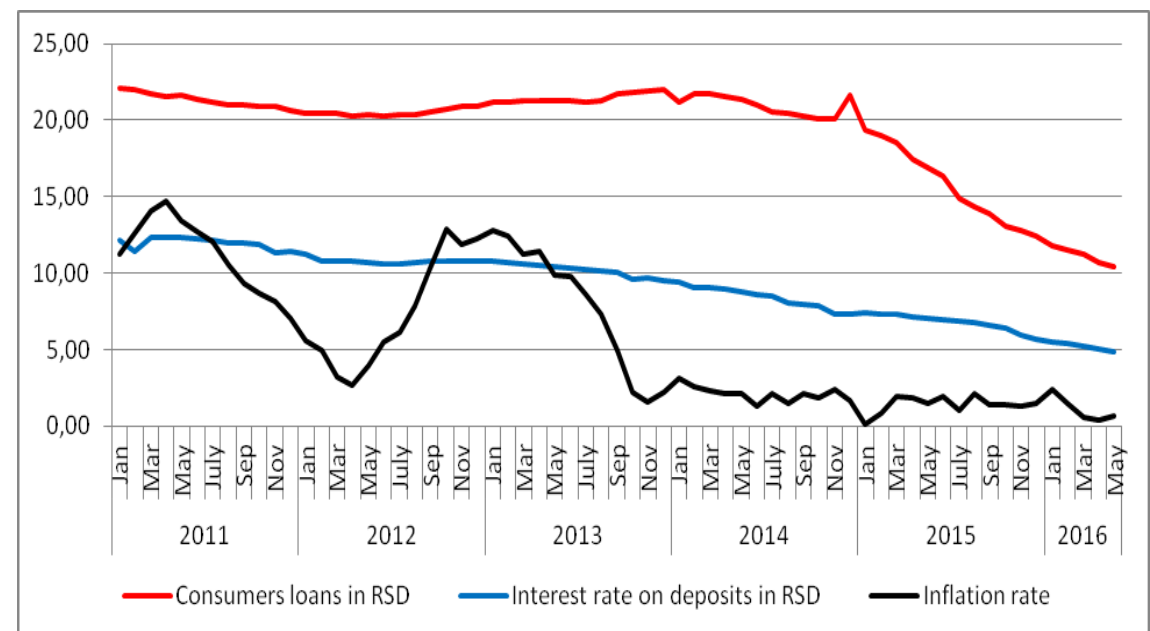

Source: NBS

In Figure 2 we can see that the movement of lending and deposit interest rates in the RSD is not conditioned by the movement of the inflation rate and inflation risk premium is not heavily involved in calculating these rates. 
Figure 3. Consumers loans in RSD, indexed to FX or FX loans and inflation rate

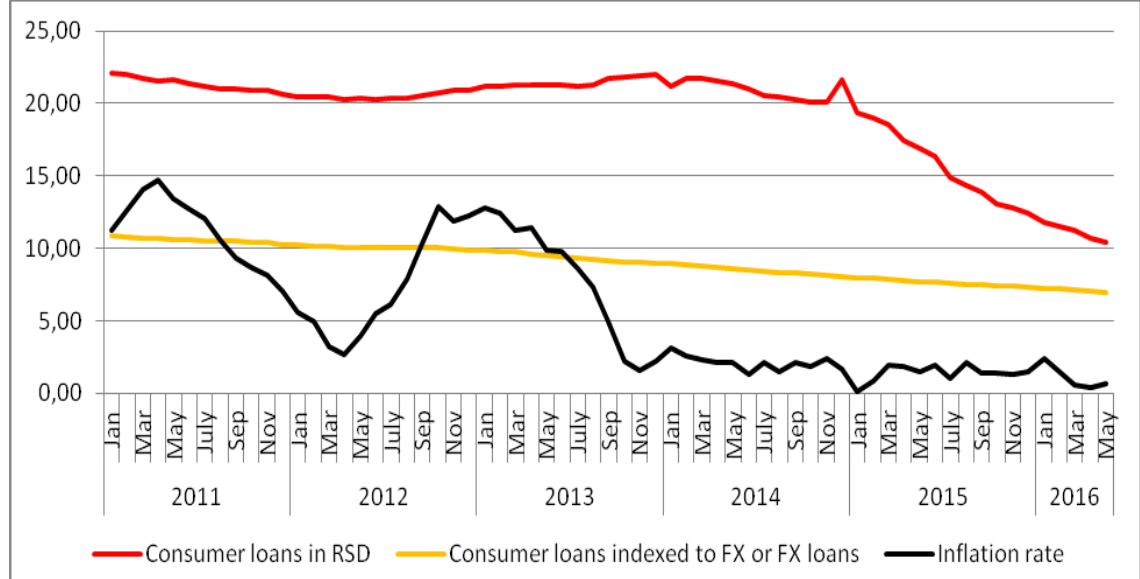

Source: NBS

Figure 4. Interest rate on deposits in RSD, indexed to FX or FX deposits and inflation rate

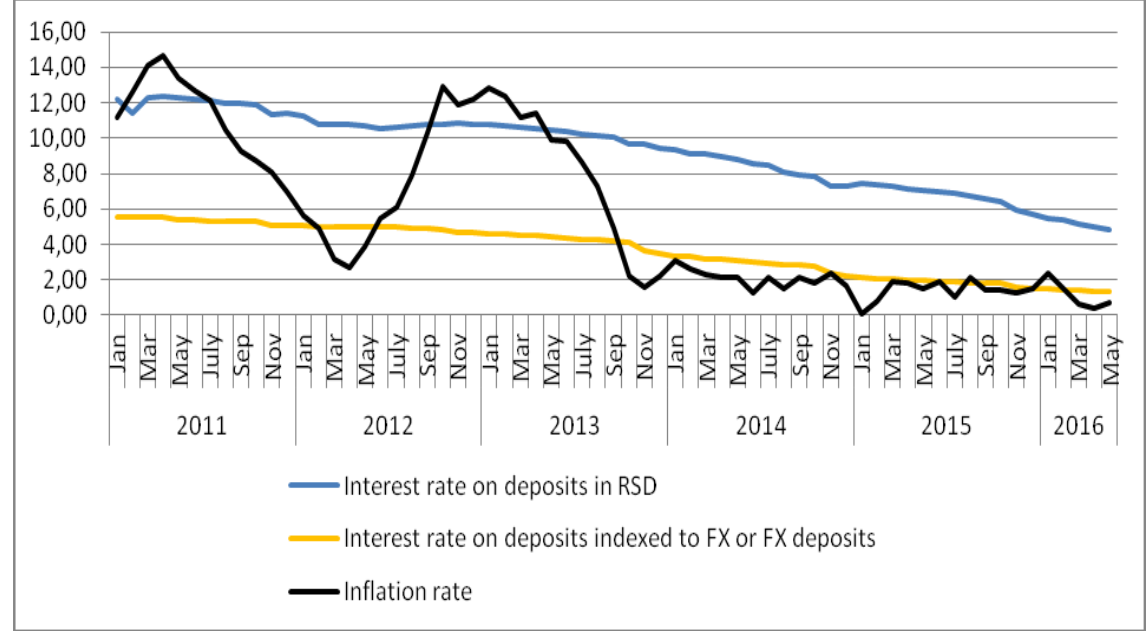

Source: NBS

Reduced impact of the interest rate channel and dominant influence of the banking sector form active and passive interest rates independently of the inflation rate, which can be seen in Figures 3 and 4. 


\section{The Dominant Influence of the Exchange Rate Channel}

The transmission mechanism of monetary policy is the process through which monetary policy affects macroeconomic aggregates such as aggregate demand, production, prices, and economic growth. It is manifested through various channels, and affects various aggregates and markets with variable speed and intensity. The identification of transmission channels enables to determine the most efficient set of monetary policy instruments and the choice on the beginning of its implementation. Current and expected monetary policies affect the money market and financial market. Changes in these markets affect the market of goods and services and, ultimately, aggregate demand, production, and prices. Finally, economic activity and inflation have reverse impact on monetary policy.

In theory, there are 4 basic transmission channels whose significance differs in different states, depending on the development of financial market:

1. Interest rate channel,

2. Credit channel,

3. Asset price channel, and

4. Exchange rate channel.

In a relatively closed economy, changes in the central bank's key policy rate lead to changes in short-term and long-term (lending and deposit) interest rates of commercial banks. In line with these changes, decisions on investments and savings of economic entities are made. In the case of the key policy rate, there has been growth of interest rates, increase in the cost of borrowing and decrease in investment activity and consumption. Time move of monetary policy operations in this transmission channel is significantly long. In developed market economies, this is the most important channel of monetary policy transmission mechanism. In Serbia, it is still not of great importance.

The credit channel of monetary transmission consists of two subcategories: the credit channel in the narrow sense and the credit channel in a broader sense. Credit channel amplifies the effects of the traditional interest rate channel. In the event of rising interest rates, there comes to a decline in investments, not only because of high costs of capital, but also due to decline in loan offers, especially to small and medium-sized enterprises. This is an important channel in countries where banks have a dominant role within financial system and where there is no complete interchangeability of bank deposits with other sources of funding.

In terms of developed financial market, asset prices play an important role in the transmission mechanism of monetary policy through the impact of monetary policy on the prices of bonds and stocks. This channel operates through a change of market value of stocks or personal wealth. Higher interest rates affect the decrease 
in stock prices, which leads to a decline in financial wealth, consumption reduction, and Tobin's q effect. ${ }^{2}$

There are several factors that influence the choice of an appropriate monetary policy transmission channel. In addition to the development level of financial market, the impact of the banking sector, transitional phase in which the country finds itself, there is also a significant impact of economic openness and connecting of the national currency to the reference currency.

In the monetary policy transmission of the National Bank of Serbia, the exchange rate channel has the dominant role. The impact of the exchange rate channel is determined by the great influence of the single currency of the euro and the ECB on our country. Specifically, in a small and open economy, such as Serbia, deposits and loans are indexed to the European currency. The share of foreign currency deposits in total deposits is about 75-80\% (Dragutinović, 2008). Then, in order to harmonise with the ECB and respect the convergence criteria, as a necessary precondition for the ECB accession, greater currency depreciation would directly affect the credibility of the NBS. In terms of the indebtedness in the euro and revenues in local currency, the devaluation of the exchange rate would not lead to an increase in exports and production, but to deterioration of the balance sheet position of the company, deleveraging (due to the increase in risk premium) and investment.

If we observe the movement of the key policy rate and exchange rate, the growth of the key policy rate, in terms of inflation, in the short term leads to nominal appreciation and reduction in inflationary pressures. Conversely, reduction in the key policy rate in the short term, leads to a depreciation of the exchange rate, due to increased demand, and fuels inflationary pressures through direct and indirect impact. Direct impact of the exchange rate means that depreciation increases domestic prices of tradable goods. Indirect impact of the exchange rate changes the ratio of the price of tradable goods and services relative to the prices of non-tradable goods. Nominal depreciation makes domestic goods cheaper than imported ones, leads to increased exports and decreased imports, the growth of aggregate demand and production. In the short term, depressed exchange rate affects the demand and production in a positive direction, but in the long term, increased demand leads to inflation.

In Serbia there is unofficial euroisation, which is the result of shaken confidence in the dinar, due to historical factors, and euro indexed loans. Unofficial euroisation has influenced the choice of the exchange rate in Serbia and need of a

\footnotetext{
2 Tobin's q ratio is named after the American economist and Nobel laureate in economics, James Tobin. In 1969, Tobin stressed the importance of the ratio of market value and capital replacement costs. If the q ratio is greater than one, there is an increase in investments and consumption.
} 
managed exchange rate. From Figure 5, it can be concluded that dinar term deposits and foreign currency deposits, despite the fact that $80 \%$ of deposits in Serbia are foreign currency indexed deposits, have a growing trend.

Figure 5. Dinar time and foreign currency deposits, in million dinars

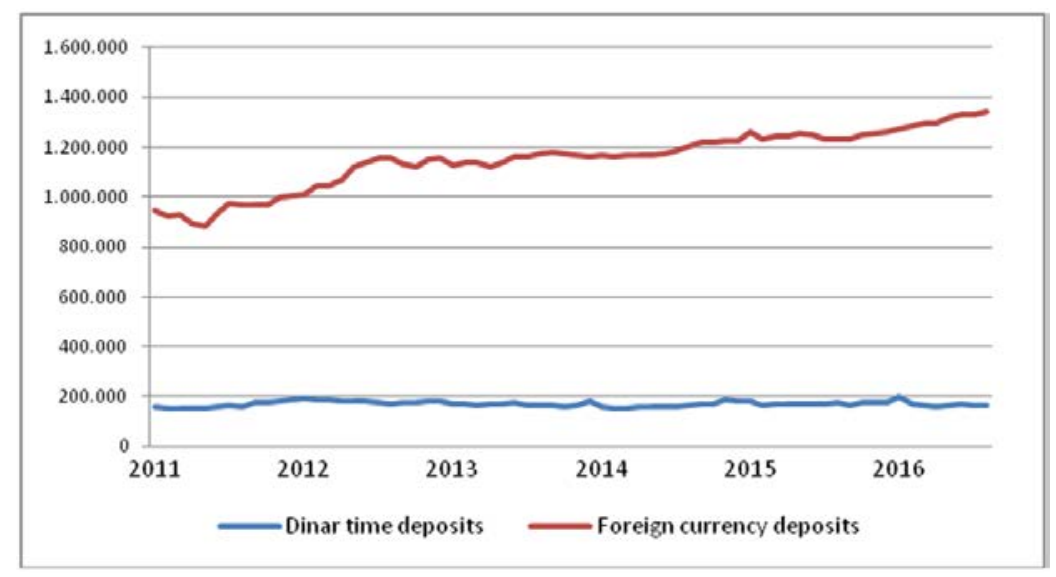

Source: NBS

Although the NBS has defined that in the inflation targeting regime foreign exchange interventions are rarely used as a secondary instrument, which contributes to the achievement of the inflation target when it has exhausted the possibility for an effective impact of the benchmark interest rate on inflation, in 2010 NBS intervened 85 times by selling 2.8 billion euro, and in the same period, bought 236 million euro. In that year, the middle rate of the dinar to the euro, despite all the interventions of the National Bank of Serbia, increased from 95.7 to 105.6 as it was the end of the year. Despite all the NBS's interventions in the past 12 years, the exchange rate of the dinar to the euro has increased by $60 \%$, from 73 which was registered in 2004 to 123 in 2016, as shown in Figure 6.

Intervening in the foreign exchange market, the National Bank of Serbia reduced foreign exchange reserves, which it is not able to cover the money supply M3. Foreign exchange reserves in recent years have a tendency to stagnate and show little growth, which can be seen in Figure 7. In Figure7 it can be seen that after rapid growth until 2007, the NBS's foreign currency reserves have been fluctuating around 10 billion euros, for almost 10 years. (Furtula \& Stojković, 2016) 
Figure 6. The exchange rate of the dinar to the euro in the period 2004-2016

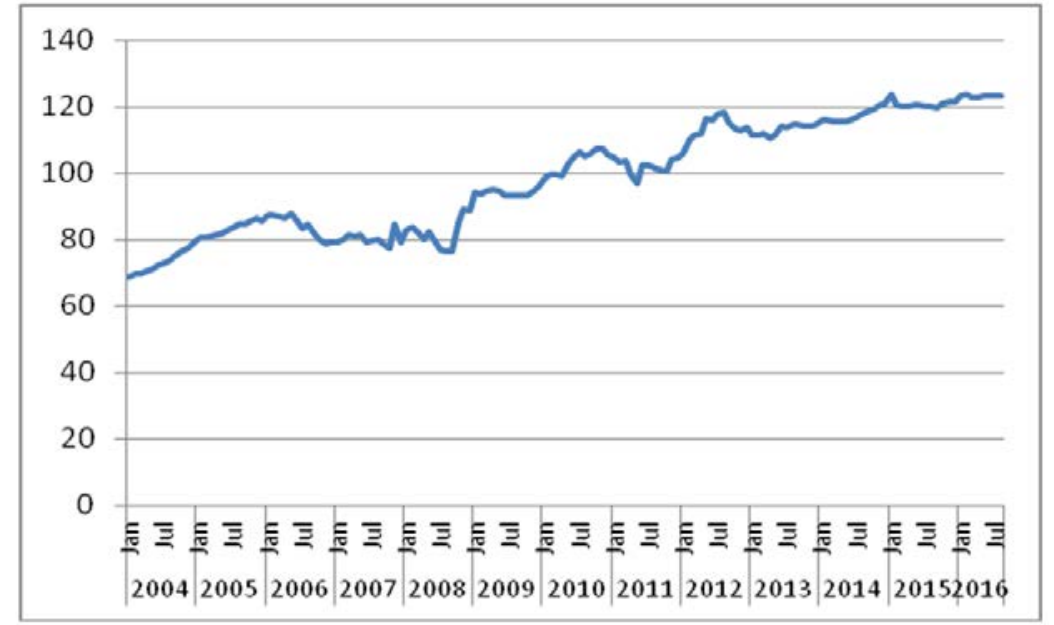

Source: NBS

Figure 7. Foreign exchange reserves of the National Bank of Serbia (gold, special drawing rights, cash and deposits in foreign loans and securities) during the period 2004-2016, in millions of euro

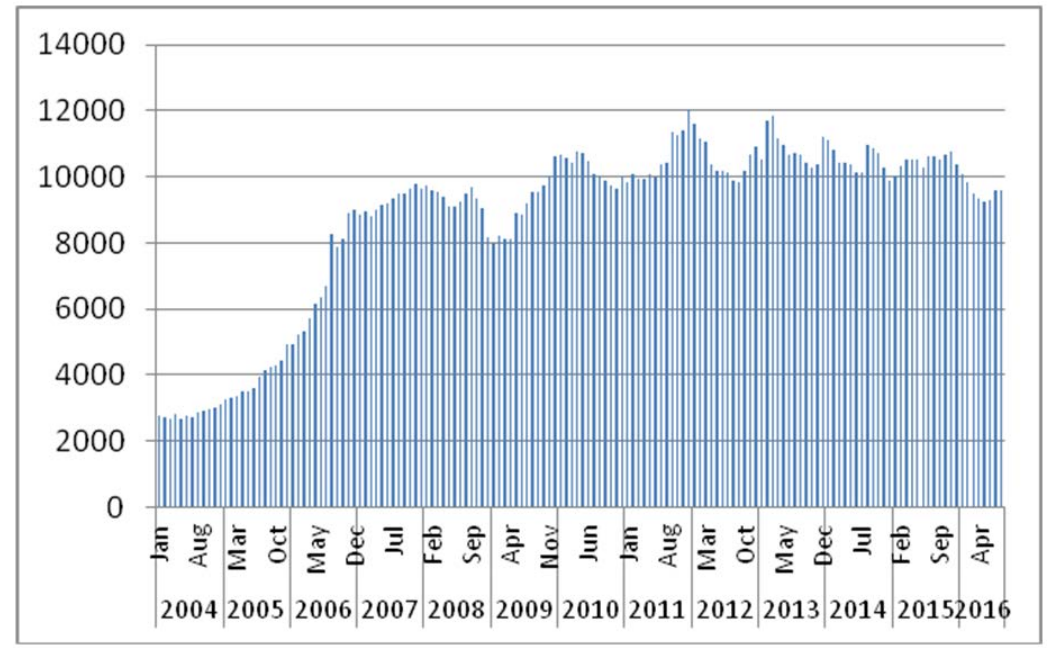

Source: NBS

\section{Conclusion}

The transmission mechanism of the monetary policy in Serbia in the first years of transition was carried out mainly through the exchange rate channel, while the 
channel of interest rates almost did not work. The impact of the exchange rate channel is determined by the great influence of the single currency of the euro and the ECB on our country. Also, reasons for not using the interest rate channel and the dominant role of the exchange rate channel derive from the characteristics of our economy and the high share of foreign currency deposits in total deposits.

In recent years, starting from 2012, drastic reduction in coverage of the money supply M3 of the NBS with foreign exchange reserves is noticeable. In 2016, coverage of the broadest monetary aggregate with foreign exchange reserves amounted to $60 \%$. Also, it is concerning that the scope and coverage of M2 has been decreasing, especially from 2012, which proves that the NBS should take into account the foreign exchange interventions which increasingly reduce the foreign currency reserves of Serbia.

There is no fully developed financial market in Serbia, which has a small width and depth, and on the other hand, there is bank-centric financial system. The dominance of banking institutions contributed to the constant increase in the relative balance of bank assets and GDP. This relationship in the previous year reached $88.4 \%$. Since there are 5 banks with a market share of over $50 \%$, it can be concluded that the financial system has the character of a solid banking oligopoly and there is low influence of key policy rate on active and passive interest rate.

Also, the increased key policy rate was in direct proportion with borrowing abroad. But in Serbia in 2008, there was an absolute disharmony of reference interest rates in developed market economies and the NBS's key policy rate. While in the United States, the reference interest rate was $0.25 \%$, in the ECB was $1.5 \%$, key policy rate of the NBS's was at the level of $17.75 \%$, which contributed to the increase in foreign borrowing. Also, since the global financial crisis, most developing countries have secured additional liquidity with expansionary monetary policy, while NBS all these years implemented mild restrictive monetary policy, with a much higher reference interest rate.

As a final conclusion of this study, the fact that the key policy rate may not be the main instrument of monetary regulation in terms of the non-functioning of the interest rate channel and unofficial euroisation could be pointed out. All instruments of the monetary policy should have the same importance in these conditions. In addition to a flexible exchange rate, which is a good solution in terms of the excessive influence of the euro, excessive intervention by foreign exchange reserves should be limited. The solution is to stabiliee the exchange rate, despite an increase in production and exports, it is necessary to prohibit the foreign currency clause in loans of banks and to limit the margin of fluctuation of buying and selling foreign exchange. Furthermore, because of credible monetary policy, it is necessary to strictly implement the Taylor rule. 


\section{References}

Bernanke, B, Mishkin, F. (1997) „Inflation Targeting: A New Framework for Monetary Policy?”, Journal of Economic Perspectives, 11(2), 97-116.

Bernanke, B. (2001) Inflation Targeting: lessons from the international experience, Princeton University Press, Oxford.

British Bankers' Association download from, Retrieved from: http://www.bba.org.uk, accessed on May 29, 2009.

Dragutinović D. (2008) Moć i nemoć monetarne politike u uspostavnjanju ravnoteže između platnobilansnih ciljeva i ciljeva inflacije, The National Bank of Serbia, Working Papers.

European Banking Federation (EFB), Retrieved from: http://www.ebf-fbe.eu, accessed on May 29, 2009.

European Central Bank (ECB) (2002) Recent Findings on Monetary Policy Transmission in the Euro Area, Monthly Bulletin.

European Money Markets Institute (EMMI), Retrieved from: http://www.euribor.org, accessed on May 29, 2009.

Furtula, S., Stojković, D. (2016) Efikasnost operacija na deviznom tržištu Narodne banke Srbije, Zbornik radova sa naučnog skupa Instititucionalne promene kao determinanta privrednog razvoja Republike Srbije, Ekonomski fakultet u Kragujevcu, Kragujevac, 335-340.

Hutchinson, I.N, Aizenman, J (2011) "Inflation Targeting and Real Exchange Rates in Emerging Markets”, World Development, 39(5), 712-724.

Hüfner, Felix (2004) Foreign Exchange Intervention as a Monetary Policy Instrument, Physica-Verlag, 2-3.

Mishkin, F. (2000) "Inflation-targeting in Emerging-Market Countries", American Economic Review, 90 (2), 105-109.

National Bank of Serbia (NBS), Retrieved from: https://www.nbs.rs/internet/cirilica/80/index.html, accessed on Jun 10, 2016.

National Bank of Serbia (NBS), Retrieved from: http://www.nbs.rs/export/internet/latinica/30/memorandum_monetarna_strategija_1 22008.pdf, accessed on March 14, 2017.

Republic of Serbia, Official Gazette, no. 72/03, 55/04, 85/05, 44/10, 76/12, 106/12, 14/15 and 40/15

Svensson, L.E.O (2001) Independent Review of the Operation of Monetary Policy in New Zealand, Report to the Minister of Finance.

Taylor, John, B. (1993) Discretion versus policy rules in practice, Carnegie-Rochester, Conference Series on Public Policy 39, 195-214.

Thomson Reuters Serbia, Retrieved from: http://thomsonreuters.rs/tr/rs/index.action, accessed on March 14, 2017.

Vestin, D. (2006) "Price-level versus inflation targeting”, Journal of Monetary Economics, 53(7), October 2006, 1361-1376. 


\section{REFERENTNA KAMATNA STOPA KAO OSNOVNI ILI POMOĆNI INSTRUMENT STRATEGIJE INFLACIONOG TARGETIRANJA U SRBIJI}

Apstrakt: U postizanju stabilnosti cena kao primarnog cilja monetarne politike, Narodna banka Srbije koristi referentnu kamatnu stopu kao osnovni instrument monetarne politike, dok ostali instrumenti imaju sekundarni karakter i doprinose nesmetanoj transmisiji referentne kamatne stope, kao i razvoju finansijskih tržišta. Međutim, zbog uslova u kojima funkcioniše ekonomski i finansijski sistem Republike Srbije, transmisioni mehanizam monetarne politike se vrši uglavnom preko kanala deviznog kursa, dok kanal kamatnih stopa gotovo da nije u funkciji. Veliki uticaj kanala deviznog kursa determinisan je velikim uticajem jedinstvene valute evra i Evropske centralne banke na našu zemlju. Stoga je cilj ovog rada da se analizira efikasnost referentne kamatne stope kao instrumenta monetarne politike, jer u poslednjih nekoliko godina osnovni instrument dobija sekundarni karakter u monetarnoj regulaciji.

Ključne reči: Narodna banka Srbije, inflacija, monetarna politika, referentna kamatna stopa, devizno tržište.

\section{Authors' biographies}

Srdan Furtula is Associate Professor at the Faculty of Economics, University of Kragujevac, Serbia, where he defended his $\mathrm{PhD}$ thesis in scientific field of Finance, Financial Institutions and Insurance. He teaches the subject Monetary Finance (undergraduate studies), and Monetary System of the European Union (master studies) at the Faculty of Economics, University of Kragujevac. His research interests include finance, monetary policy and monetary integration.

Milan Kostić is Assistant Professor at the University of Kragujevac, Faculty of Economics. He holds a PhD in Economics at the University of Kragujevac. He teaches the Theory of Prices at the bachelor level, the Globalisation and Transition at the master level and the Competition analyses at $\mathrm{PhD}$ studies. The main areas of interest are: inflation theory, theory of prices, microeconomics, competition policy and consumer ethnocentrism. 